\title{
Multiple Methods of Teaching Arts Between Past and Present in Jordanian Universities
}

\author{
Dr. Mosab Mahmoud Al-Qudah ${ }^{1}$ Dr. Jehad Hasan Alameri ${ }^{2}$ \\ Dr. Haifa'a Ahmad Bani Ismail ${ }^{3}$ Dr. Isam Elsayed Ibada Allam ${ }^{3}$ \\ Dr. Mutasem Azmi Al-karablieh ${ }^{3}$ Dr. Ibrahim Ahmad Al-Khatib ${ }^{3}$ \\ 1.Lecturer, The University of Jordan, College of Art and Design, Department of Visual Arts \\ 2.Associate Professor, The University of Jordan, College of Art and Design, Department of Visual Arts \\ 3.Assistant professor, The University of Jordan, College of Art and Design, Department of Visual Arts
}

\begin{abstract}
The study in concepts of Fine Arts educational methods in the Jordanian Universities from the perspectives of instructors in Fine Arts faculty at Yarmouk University and Arts and design faculty at Jordanian University in the academic year 2019/2020, the researcher used the descriptive analyses approach. The study population consists of Fine Arts faculty instructors at Yarmouk University (55) and Arts and design faculty instructors in the Jordanian University (32)with 87. The study tool was applied to the plastics art department instructors with a number (26) and with a percentage (98\%). To achieve the study's goal, the researcher has conducted a 56-items questioner distributed on five main areas: the purposes of teaching Fine Arts, the reality of Fine Arts teaching, modern teaching methods, Fine Arts attitudes, and Fine Arts learning approaches. The validity and reliability of the tool have been verified.The study results showed that teaching Fine Arts objectives were high in the Jordanian universities with an average (2.54). The reality of Fine Arts teaching in the Jordanian universities was high with average $(2.39$, the fine arts teaching methods used in the Jordanian universities were high with average $(2,42)$. According to instructors ' perspective, attitudes toward Fine Arts in the Jordanian universities were high with average $(2,45)$, and the effectiveness of teaching approaches used in teaching Fine Arts in the Jordanian universities was high with average $(2,48)$. On light of the previous results, the researcher recommended some recommendations to modernize Fine Arts teaching methods.
\end{abstract}

Keywords: Concept changes, Good perception of meaning, Fine arts, Teaching Methods

DOI: $10.7176 / \mathrm{JTHS} / 52-04$

Publication date: December $31^{\text {st }} 2020$

\section{Introduction}

Like other sciences, art is concerned with promoting human and scientific knowledge and directing it towards innovation. Perhaps the interest in teaching arts to students is a strong factor in understanding different sciences. Arts can become tools for self-use and interactive use, stimulating intuition and senses together and providing minds with skills and vocabulary that serve as a springboard for creativity and distinction. Eckert (2006) asserts that art is no less a role than other sciences in preparing individuals for the real world, where art is essential in helping the brain reach its full potential, as it exposes the brain to the various cognitive skills that help us uncover complex problems. Art activates the specialized part of the brain interested in intellectual and creative processes.

Modern educational trends indicate the trend towards developing each learner's capabilities and teaching him how to learn according to his educational needs, as they may be similar in some aspects and may differ in other aspects from the needs of his peers. And this requires the individualization of the teaching process to suit the individual's needs in terms of subject matter, educational tasks, appropriate teaching methods, and diversification of academic positions, activities, and methods of guidance and counseling. It also indicates the importance of centering education around special abilities, thus providing more significant opportunities for every student to advance in the educational process according to his abilities and scientific and technical level (Abdul Razzaq, 2002). Modern art methods are one of the principal axes of the teaching process in the field of fine arts, as effective teaching is not just a job, but rather a process of designing a vast, bifurcated project that has clear foundations for its direct connection with the future of those we teach. Technical teaching methods are considered those relationships that arise between the teacher and the student and affect, positively or negatively, the achievement of the goals set for the technical lesson. The development of modern technologies in art education has created a new relationship between the student and the teacher in the process of knowledge and educational attainment, which creates a new type of artistic activities dependent on self-education (Al-Hamid, 2003).

Habash (2002) indicated the necessity of adopting more advanced educational methods and strategies, stressing that the teaching and learning process is no longer merely an indoctrination on the part of the teacher and memorization on the part of the student. Instead, it is a process of communication and joint thinking between the teacher and the student, and deep interaction with the private and public environment, near and far, in the present and future. There are many teaching methods as classified by (Khaza'leh and others, 2011) into eight methods, namely: the method of memorization and recitation, the method of lecturing (delivery), method of accountability 
and questioning, method of discussion and dialogue, method of problem-solving, method of presentation, story method, and finally, project method.

The teacher's role comes to choose the appropriate teaching method for the subject matter and the students' experiences and abilities, where the teacher's role is as the director of the teaching process. He plans the teaching process and then organizes the experiences and prepares the appropriate teaching environment to achieve the goals. The teacher is considered a leader for the educational activities, as he controls and controls the teaching process while giving the educational material. A good teacher is constantly looking for new educational methods to learn more and improve his teaching skills (Ayesh, 2008).

The role of universities comes as educational institutions that play the largest role in crystallizing the students' values system, placing it in its appropriate framework and sound image, and finding appropriate ways to deliver it to work to consolidate and enhance it for them, especially as it works to prepare them to engage in practical life. The role of universities lies in reducing and strengthening educational values in society to prevent them from distorting, Misrepresenting, or destroying them (Abdel-Hay, 2007).

Despite the opening of the Faculties of Fine Arts and Design and the success of these colleges in preparing a generation of Jordanian and Arab artists and preparing a generation of fine art teachers in Jordanian schools, however, the process of researching and developing art education methods in Jordanian universities has rarely been discussed in scientific conferences or research. The study's problem is determined by the scarcity of reporting to monitor the reality of conceptual changes in teaching methods, which constitutes an obstacle to developing methods of teaching fine arts. The teaching methods used remain individual for some and not systematic at times.

\section{The Study Objectives}

This study aims to:

- Monitor the perceptual changes in teaching fine arts in Jordanian universities for the first semester of the academic year 2019-2020 from the viewpoint of the professors of the Faculty of Fine Arts at Yarmouk University and the Faculty of Art and Design at the University of Jordan.

- $\quad$ Know the extent to which perceptual changes in the methods of teaching art in Jordanian universities affect students.

- Learn about the reality of teaching fine arts in Jordanian universities.

- $\quad$ Know the degree of effectiveness of fine arts education curricula in Jordanian universities. 2019/2020.

\section{The methodology of the Study \\ The Study Population}

The study population consisted of all professors and teachers of the Faculties of Fine Arts at the university and the College of Art and Design at the University of Jordan, and their number (87) faculty members for the academic year 2019/2020.

\section{The Study Sample}

The study sample consisted of professors and teachers of the College of Fine Arts at Yarmouk University / Department of Fine Arts, and professors and teachers of the College of Art and Design / Department of Visual Arts at the University of Jordan, and their number (26) faculty members for the first semester of the academic year $2019 / 2020$.

\section{The Study Tool}

The researcher prepared a study tool (questionnaire) consisting of (56) items distributed into five domains, namely:

The first domain: The objectives of teaching fine arts, it consisted of (15) items.

The second domain: the reality of teaching fine arts, consisted of (15) items.

The third domain: modern teaching methods in fine arts, consisted of (11) items.

The fourth domain: The trends in fine arts and the number of its items is (7).

The fifth domain: curricula for teaching fine arts, it consisted of (8) items.

\section{The validity of the study tool}

The researcher verifies the validity of the tool by presenting it to a group of specialized arbitrators from Jordanian universities to express their observations in terms of:

- Accuracy and integrity of phrasing.

- $\quad$ Suggest appropriate paragraphs.

- Modify paragraphs.

- The extent to which the paragraphs belong to their domains.

And after taking into account the comments of the arbitrators and their directions, in terms of deleting some of the repeated paragraphs and adding what they deem appropriate. The questionnaire became in its final form 
consisting of (56) items distributed into five areas: "The Objectives of Teaching Fine Arts" includes (15) items, "The Reality of Teaching Fine Arts" includes (15) items, "Modern Teaching Methods" includes (11) items, and "Trends in Fine Arts" includes (7) items, And "Curricula for Teaching Fine Arts" includes (8) items.

\section{Study procedures}

\section{The researcher took the following steps to implement the study:}

- $\quad$ Defining the study problem, its questions, and its variables.

- $\quad$ Refer to the theoretical literature and previous studies related to the study problem.

- $\quad$ Study tool preparation through theoretical literature.

- $\quad$ Ensure the study tool's validity by submitting it to a group of specialized arbitrators and taking their opinions.

- Verify the study tool's stability by applying it to an intentional sample and then Pearson and Cronbach's Alpha coefficients with internal consistency.

- Entering data into the computer and extracting and analyzing statistical results.

- Discuss the results of the study and make recommendations in light of the results.

\section{Reliability of the study tool}

The researcher verified the study tool's reliability by applying it to an intentional sample from within the study sample's scope, and to ensure the reliability of the tool, the internal consistency was calculated according to the Cronbach Alpha equation, and Table (1) shows these parameters. And these percentages were considered suitable for this study.

\section{Table 1: Cronbach Alpha internal consistency coefficient}

\begin{tabular}{ll} 
Domains & Internal consistency \\
\hline The goals of teaching fine arts as a whole & 0.89 \\
The reality of teaching fine arts as a whole & 0.83 \\
Modern teaching methods in fine arts as a whole & 0.84 \\
Trends in Fine Art as a Whole & 0.77 \\
Curricula for teaching fine arts as a whole & 0.75 \\
Total marks & 0.91 \\
\hline
\end{tabular}

\section{Statistical treatment}

The statistical treatment includes a detailed presentation of the results of the study, according to the following question: "What are the changes in the concepts of the methods of teaching fine arts in Jordanian universities," which resulted in the following sub-questions:

Results of the first question: What are the goals of teaching fine arts in Jordanian universities?

To answer this question, arithmetic averages and standard deviations were extracted to teach fine arts in Jordanian universities, and the table below illustrates this. 
Table 2: Mean and standard deviations for the objectives of teaching fine arts in Jordanian universities arranged in descending order according to the arithmetic averages

\begin{tabular}{|c|c|c|c|c|c|}
\hline Rank & $\mathbf{N}$ & Items & Mean & $\begin{array}{l}\text { standard } \\
\text { deviation }\end{array}$ & Level \\
\hline 1 & 1 & $\begin{array}{l}\text { Introduce students to fine arts and their relationship with } \\
\text { different civilizations. }\end{array}$ & 2.88 & .326 & High \\
\hline 2 & 8 & Introduce students to technical concepts and terms. & 2.62 & .496 & High \\
\hline 3 & 7 & $\begin{array}{l}\text { Developing students' abilities to gain an artistic appreciation } \\
\text { of aesthetic values. }\end{array}$ & 2.58 & .504 & High \\
\hline 3 & 10 & Discover artistically gifted students. & 2.58 & 578. & High \\
\hline 3 & 11 & $\begin{array}{l}\text { Taste and appreciate the achievements of Arab and } \\
\text { international artists. }\end{array}$ & 2.58 & 504. & High \\
\hline 6 & 2 & $\begin{array}{l}\text { Defining the aesthetic and artistic values of the } \\
\text { environmental and folklore components. }\end{array}$ & 2.54 & 508. & High \\
\hline 6 & 3 & $\begin{array}{l}\text { Work to develop innovative artistic ideas according to } \\
\text { students' abilities. }\end{array}$ & 2.54 & 706. & High \\
\hline 6 & 9 & The use of various activities in teaching courses. & 2.54 & 508. & High \\
\hline 6 & 12 & $\begin{array}{l}\text { The development of skills and abilities that help in the } \\
\text { knowledge of contemporary modern theories. }\end{array}$ & 2.54 & 508. & High \\
\hline 10 & 4 & $\begin{array}{l}\text { Developing students' abilities to describe, analyze, and } \\
\text { compare artistic works on an individual and group level. }\end{array}$ & 2.50 & 583. & High \\
\hline 10 & 5 & $\begin{array}{l}\text { Familiarizing students with the various artistic innovations } \\
\text { and trends of the past and present. }\end{array}$ & 2.50 & 648. & High \\
\hline 10 & 6 & The use of environmental materials in artistic works & 2.50 & 648. & High \\
\hline 13 & 15 & $\begin{array}{l}\text { Unloading students' energies by practicing technical work } \\
\text { and application. }\end{array}$ & 2.46 & 647. & High \\
\hline 14 & 13 & $\begin{array}{l}\text { Visiting the various learning resources at the university with } \\
\text { students. }\end{array}$ & 2.38 & 697. & High \\
\hline \multirow[t]{2}{*}{15} & 14 & $\begin{array}{l}\text { The student's awareness of art as a means of communication } \\
\text { between diverse cultures. }\end{array}$ & 2.31 & 618. & Average \\
\hline & & The goals of teaching fine arts as a whole & 2.54 & 369. & High \\
\hline
\end{tabular}

Table (2) shows that the arithmetic averages ranged between (2.31-2.88), While Paragraph No. (1), which states "introducing students to fine arts and its relationship with different civilizations," came first, with a mean of (2.88), and at a high level. While item (14), which states "the student's perception of art as a means of communication between various cultures," came last, with an arithmetic mean of (2.31), with an average level, the arithmetic means of the goals of teaching fine arts as a whole was (2.54), with a high average.

The second question: What is the reality of teaching fine arts in Jordanian universities?

To answer this question, arithmetic averages and standard deviations of the reality of teaching fine arts in Jordanian universities were extracted, and the table below illustrates this. 
Table 3: Mean and standard deviations of the reality of teaching fine arts in Jordanian universities arranged in descending order according to the arithmetic means

\begin{tabular}{|c|c|c|c|c|c|}
\hline Rank & Number & Items & Mean & $\begin{array}{l}\text { standard } \\
\text { deviation }\end{array}$ & Level \\
\hline 1 & 16 & $\begin{array}{l}\text { Identify students 'abilities and previous technical } \\
\text { experiences before submitting the material and linking } \\
\text { new knowledge with learners' experiences. }\end{array}$ & 2.58 & 504. & High \\
\hline 1 & 17 & Using modern audiovisual aids in teaching courses. & 2.58 & 504. & High \\
\hline 3 & 19 & Clarify the main ideas of the lecture and link them. & 2.54 & .582 & High \\
\hline 4 & 18 & $\begin{array}{l}\text { Assigning students to artistic research that helps them } \\
\text { to think constructively and create artistic creativity. }\end{array}$ & 2.50 & 583. & High \\
\hline 5 & 30 & $\begin{array}{l}\text { Participation of students in preparing the necessary } \\
\text { tools for practical technical application to equip } \\
\text { students with different skills. }\end{array}$ & 2.46 & 508. & High \\
\hline 6 & 24 & $\begin{array}{l}\text { Giving an appropriate coursebook that enriches } \\
\text { students with the necessary technical information. }\end{array}$ & 2.42 & 578. & High \\
\hline 6 & 29 & $\begin{array}{l}\text { Students acquire technical skills to reach the highest } \\
\text { creativity skills. }\end{array}$ & 2.42 & 504. & High \\
\hline 8 & 25 & Diversity in the use of questions to enrich the topics. & 2.38 & 697. & High \\
\hline 8 & 28 & $\begin{array}{l}\text { Participate in beautifying the surrounding environment } \\
\text { and society through conducting field workshops. }\end{array}$ & 2.38 & 637. & High \\
\hline 10 & 20 & $\begin{array}{l}\text { Adopting the sequence of lectures according to logical } \\
\text { and gradual lines. }\end{array}$ & 2.35 & 629. & High \\
\hline 10 & 22 & $\begin{array}{l}\text { The ability to produce appropriate educational aids that } \\
\text { serve the required academic material. }\end{array}$ & 2.35 & 745. & High \\
\hline 10 & 27 & $\begin{array}{l}\text { Determine a suitable homework assignment for } \\
\text { students. }\end{array}$ & 2.35 & 629. & High \\
\hline 13 & 26 & $\begin{array}{l}\text { End the lecture with an oral or briefing summary } \\
\text { highlighting its general elements. }\end{array}$ & 2.27 & 724. & Average \\
\hline 14 & 23 & $\begin{array}{l}\text { Diversity in the content of the educational material } \\
\text { given in the lectures. }\end{array}$ & 2.15 & 784. & Average \\
\hline \multirow[t]{2}{*}{15} & 21 & $\begin{array}{l}\text { Connecting the theoretical and practical side when } \\
\text { giving lectures. }\end{array}$ & 2.12 & 711. & Average \\
\hline & & The reality of teaching fine arts as a whole & 2.39 & .345 & High \\
\hline
\end{tabular}

Table (3) shows that the arithmetic averages ranged between (2.39-2.58), where items (16) and (17) came which provide for "identifying students 'abilities and previous technical experiences before starting to provide the material and linking new knowledge with the learners' experiences." "The use of modern audiovisual aids in teaching courses" in the first place, with an arithmetic average of (2.58), and a high level, While paragraph No. (21), which states: "Linking the theoretical and practical side when giving lectures" to the last rank, with an arithmetic average of (2.12), with an average level. The average of the reality of teaching fine arts as a whole was (2.39), with a high level.

The third question: What are the modern teaching methods in fine arts in Jordanian universities?

To answer this question, the arithmetic means and standard deviations of modern teaching methods used in Jordanian universities were extracted, and the table below illustrates that. 
Table 3: Means and standard deviations of the items of modern teaching methods used in Jordanian universities arranged in descending order according to the arithmetic means

\begin{tabular}{|c|c|c|c|c|c|}
\hline Rank & Number & Items & Mean & $\begin{array}{l}\text { Standard } \\
\text { deviation }\end{array}$ & Level \\
\hline 1 & 32 & To employ e-mail technology to communicate with students. & 2.54 & 508. & High \\
\hline 1 & 36 & $\begin{array}{l}\text { Using the art file in the teaching and evaluation of artistic } \\
\text { works. }\end{array}$ & 2.54 & 647. & High \\
\hline 3 & 34 & $\begin{array}{l}\text { The methods currently used target the imposition of academic } \\
\text { style. }\end{array}$ & 2.46 & .582 & High \\
\hline 3 & 41 & $\begin{array}{l}\text { Using the problem-solving method in various traditional } \\
\text { courses. }\end{array}$ & 2.46 & .582 & High \\
\hline 5 & 37 & Use the role-playing method in teaching. & 2.42 & 643. & High \\
\hline 5 & 38 & Use of good teaching method standards (quality indicators). & 2.42 & 578. & High \\
\hline 7 & 31 & $\begin{array}{l}\text { Making use of contemporary theories of art education in } \\
\text { teaching arts. }\end{array}$ & 2.38 & 571. & High \\
\hline 7 & 33 & Using the demonstration method (live/televised) in teaching. & 2.38 & 637. & High \\
\hline 7 & 40 & $\begin{array}{l}\text { Participate in training courses to use modern educational } \\
\text { methods in education. }\end{array}$ & 2.38 & 496. & High \\
\hline 10 & 39 & $\begin{array}{l}\text { The use of the teaching regional laboratory technology (a } \\
\text { project that aims to support the teaching of art education in } \\
\text { organized and modern ways by developing three teaching } \\
\text { sources, which are visual analysis, production, and image } \\
\text { analysis). }\end{array}$ & 2.31 & 618. & Average \\
\hline \multirow[t]{2}{*}{11} & 35 & Use the discovery method of teaching. & 2.27 & 667. & Average \\
\hline & & Modern teaching methods as a whole & 2.42 & 370. & High \\
\hline
\end{tabular}

Table (4) shows that the arithmetic averages ranged between (2.27-2.54), as paragraphs (32) and (36) came which stipulate "employing the E-mail technology to communicate with students." And "The use of the art file in the teaching and evaluation of artistic works" is in the first place, with an arithmetic average of (2.54), and with a high level, while Paragraph No. (35) which states "The use of the discovery method in teaching" Came in the last place, with Arithmetic average of (2.27), with an average level. The arithmetic average of fine arts teaching methods was (2.42) with a high level.

The fourth question: What are the trends towards fine arts in Jordanian universities from their teachers' viewpoint?

To answer this question, arithmetic averages and standard deviations of trends towards fine arts in Jordanian universities were extracted from the viewpoint of their teachers, and the table below illustrates that.

Table 5: Means and standard deviations of trends towards fine arts in Jordanian universities from the viewpoint of their teachers arranged in descending order according to the arithmetic averages

\begin{tabular}{|l|l|l|l|l|l|}
\hline Rank & $\mathrm{N}$ & Items & Mean & standard deviation & Level \\
\hline 1 & 42 & $\begin{array}{l}\text { Helping students to understand and accept contemporary } \\
\text { artistic developments. }\end{array}$ & 2.54 & 508. & High \\
\hline 2 & 43 & $\begin{array}{l}\text { Helping the student to express his opinion and develop his } \\
\text { own culture. }\end{array}$ & 2.46 & 508. & High \\
\hline 2 & 46 & Adhere to the academic style in portraying visual facts & 2.46 & 647. & High \\
\hline 4 & 45 & Desire to adapt to modern methods and technologies. & 2.42 & 643. & High \\
\hline 4 & 47 & $\begin{array}{l}\text { Students' awareness of the aesthetics in artistic and other } \\
\text { works. }\end{array}$ & 2.42 & 578. & High \\
\hline 4 & 48 & $\begin{array}{l}\text { The difference in developing students' abilities to perceive } \\
\text { and appreciate art according to modern trends. }\end{array}$ & 2.42 & 703. & High \\
\hline 7 & 44 & Adhere to the old and prevailing educational methods. & 2.38 & 637. & High \\
\hline & & Trends in fine art as a whole & 2.45 & 397. & High \\
\hline
\end{tabular}

Table (5) shows that the arithmetic averages ranged between (2.38-2.54). Paragraph No. (42), which states 
"helping students understand and accept contemporary technical developments" came first, with an arithmetic average of (2.54), and at a high level, while paragraph No. (44), which states: "Adherence to the old and prevailing educational methods" ranked last, with an arithmetic average of (2.38), and a high level. The arithmetic mean of trends in the fine arts as a whole is (2.45).

The fifth question: What is the degree of effectiveness of fine arts education curricula in Jordanian universities?

The arithmetic means and standard deviations of the degree of effectiveness of fine arts teaching curricula in Jordanian universities were extracted to answer this question, and the table below illustrates this.

Table 6: Means and standard deviations of the degree of effectiveness of fine arts education curricula in Jordanian universities arranged in descending order according to arithmetic averages

\begin{tabular}{|c|c|c|c|c|c|}
\hline Rank & $\mathbf{N}$ & Items & Mean & $\begin{array}{l}\text { standard } \\
\text { deviation }\end{array}$ & Level \\
\hline 1 & 55 & $\begin{array}{l}\text { Change the content of art education to reflect an interest } \\
\text { in contemporary theories in art. }\end{array}$ & 2.65 & 485. & High \\
\hline 2 & 54 & $\begin{array}{l}\text { The current curricula in arts take into account the needs } \\
\text { of society. }\end{array}$ & 2.62 & 496. & High \\
\hline 2 & 56 & $\begin{array}{l}\text { The content of art education has changed to reflect an } \\
\text { interest in contemporary theories in art. }\end{array}$ & 2.62 & 496. & High \\
\hline 4 & 53 & $\begin{array}{l}\text { The curriculum is concerned with the quality of } \\
\text { standards as an entry point to ensure art teaching } \\
\text { quality. }\end{array}$ & 2.58 & 504. & High \\
\hline 5 & 52 & $\begin{array}{l}\text { Curriculum development developers look at the most } \\
\text { important global trends and experiences. }\end{array}$ & 2.38 & 697. & High \\
\hline 6 & 49 & $\begin{array}{l}\text { Current curricula in the arts are based on the } \\
\text { experiences and interests of students. }\end{array}$ & 2.35 & 485. & High \\
\hline 6 & 51 & $\begin{array}{l}\text { The arts curriculum is concerned with artistic culture } \\
\text { and contemporary thought. }\end{array}$ & 2.35 & 562. & High \\
\hline \multirow[t]{2}{*}{8} & 50 & $\begin{array}{l}\text { Current arts curricula imply a student's awareness of } \\
\text { civilizational history and cultural development. }\end{array}$ & 2.27 & 452. & Average \\
\hline & & Curricula for teaching fine arts as a whole & 2.48 & 285. & High \\
\hline
\end{tabular}

Table (6) shows that the arithmetic averages ranged between $(2.27-2.65)$, where paragraph No. (55) which states "changing the content of art education to reflect an interest in contemporary theories in art." came in the first place, with an arithmetic average of (2.65) and a high level, while paragraph No. (50), which states: "The current arts curriculum implies the student's awareness of civilizational history and cultural development" at the last rank, with an arithmetic average of (2.27) at an intermediate level, the arithmetic mean of the fine arts curricula as a whole was (2.48), with a high level.

\section{Discussion of the results of statistical analysis}

This study aimed to identify the perceptual changes in the methods of teaching fine arts in Jordanian universities. The study results showed that the perceptual changes in the methods of teaching fine arts in Jordanian universities are of a (high) degree in all fields and performance as a whole. And the field of goals for teaching fine arts came first. Where the arithmetic average reached (3.54) with a high degree, the researcher may attribute the result to the faculty members 'awareness of conceptual changes in teaching fine arts. It shows the awareness of faculty members of fine arts methods. As for the scope of the aims of teaching fine arts, it may be attributed to their clear interest in art education goals.

First: Discussing the results related to the first question

The question states: What are the goals of teaching fine arts in Jordanian universities?

The results of the study showed that the goals of teaching fine arts in Jordanian universities are (with a high degree), in all the paragraphs of the first field, except for the student's perception of art as a means of communication between various cultures, it was averaged with a mean of (2.31). Whereas, Paragraph No. (1), which states "introducing students to fine arts and its relationship with different civilizations," came in the first place, with an arithmetic average of (2.88) and a high level. The researcher may be attributed to the lack of students' mixing with the various cultures associated with other societies.

Second: Discussing the results related to the second question

The question states: What is the reality of teaching fine arts in Jordanian universities?

The study results showed that the reality of teaching fine arts in Jordanian universities is of a high degree, with an 
average of (2.39). The researcher may attribute this to the extent of the faculty members 'awareness of the importance and necessity of teaching fine arts, as reflected in the students' future societal life. Where paragraphs (16) and (17) came, which stipulate "identifying students 'capabilities and previous technical experiences before starting to submit the material and linking new knowledge with the learners' experiences." And "the use of modern audiovisual aids in teaching courses" came first, with a mean of (2.58), and at a high level, the arithmetic averages ranged between (2.58.504.). The researcher may attribute this to the interest of faculty members and their familiarity with the importance of their prior knowledge of students' abilities and previous experiences to give the appropriate educational material and choose the appropriate method for students' individual differences. Item No. (21) states: Linking the theoretical and practical aspect when giving lectures to the last rank, with an arithmetic average of (2.12), with an average level. The researcher attributed that to the fact that the focus of the teachers of the Faculty of Fine Arts comes to each aspect separately.

\section{Third: Discussing the results related to the third question}

The question states: What are modern arts teaching methods used in Jordanian universities?

The study results showed the degree of using modern teaching methods with a high degree and with an arithmetic average of (2.42). The researcher may attribute this to the faculty members 'awareness of using modern teaching methods in fine arts to reach the teaching process's desired goals. Where the paragraphs (32) and (36) came, which states: "Employing the E-mail technology to communicate with students" and "Using the Art File in Teaching and Evaluating Artistic Works" ranked first, with an arithmetic average of (2.54), and a high level. The researcher attributes this to the ease and widespread use of e-mail technology among students, the speed of information access, and the acquisition of time and effort to deliver information. The researcher attributes that the use of the art file increases the student's earnings by viewing the works of art and stimulating new artistic works because of the experience and observation he enjoys. While paragraph No. (35), which states: "The use of discovery method in teaching," ranked last, with an arithmetic average of (2.27), with a medium level. The researcher attributes the university administration's lack of interest in technical seminars and conferences due to the financial deficit currently going through Jordanian universities.

\section{The fourth question: What are the trends towards fine arts in Jordanian universities from their teachers' viewpoint?}

The results of the study showed that the trends in fine arts were high (2.45). The researcher attributes this to the faculty members' motivation to help students know and work on the various artistic trends. Where came paragraph No. (42), which states: "Helping students to understand and accept contemporary artistic developments" in the first place, with a mean of (2.54), and with a high level, the researcher attributes this to the importance of students' acceptance of contemporary artistic developments to advance and innovate the artistic process. While paragraph No. (44), which states: "Aence to the old and prevailing educational methods," ranked last, with an arithmetic average of (2.38), and a high level. The researcher attributes this to the fact that the nature of the technical material sometimes requires old and prevailing educational methods.

\section{The fifth question: What is the degree of effectiveness of fine arts education curricula in Jordanian} universities?

The study results showed that the degree of effectiveness of fine arts teaching curricula in Jordanian universities came at a high level (2.48). The researcher attributed this to the awareness and perception of the faculty members. And the importance of activating art education curricula commensurate with students' abilities, preferences, and goals required of the art teaching process. Where came paragraph No. (55), which states: Changing the content of art education to reflect an interest in contemporary theories in art. "In the first place, with an arithmetic average of (2.65), at a high level, the researcher attributes this to the interest in modern and contemporary theories in art and content commensurate with modernity. While paragraph No. (50), which states: "The current arts curriculum implies the student's awareness of civilizational history and cultural development" at the last rank, with an arithmetic average of (2.27) at an intermediate level, the researcher attributes this to the cultural history and cultural development dimension to a certain extent from fine arts curricula and the lack of introduction of the civilizational history and cultural development.

\section{Study Results}

This study aimed to present a set of art teaching methods used in teaching fine arts in general, and a set of approaches were chosen to update the methods of teaching fine arts. Such as methods of teaching fine arts between traditional and modernity, conventional methods of teaching fine arts, and modern teaching methods in fine arts and the professional artist's association with fine arts colleges, art museums and galleries, changing the concepts of fine arts teaching methods, and their connection to the reality of the communication revolution and the reality of teaching fine arts in Jordanian universities. 


\section{Among the most important findings of the study are:}

1. Teaching art is a science that is still developing with the development of contemporary concepts and theories of teaching methods, and that there are learning strategies through which you can improve information awareness among art students in Jordanian universities, and that is through those in charge of the educational process, critics and art historians. The professional artist's important role is that they all systematically contribute to the content of art education.

2. There is a vital role for faculty members in colleges of art towards students to provide them with information awareness and skill, of the most important concepts and recent changes in the arts, methods of accessing them and using them in research and evaluation processes, and the use of modern electronic technologies.

3. The modern teaching methods presented in this research work to develop and improve the quality of understanding and perception so that the art student is more able to observe, more aware, and has more feeling or a sense of fine arts.

4. Most of the art colleges in Jordanian universities still lack close links between them and similar international universities and academies, which reduces the exchange of experiences at the scientific and cultural level and closely identifies the most critical variables in teaching fine arts at the global level.

5. This study showed the role that universities and colleges of art have to make strong relationships more related to art museums and galleries, whether they are within societies of countries or at the global level, or those on the World Wide Web for a richer, more quality education, which in turn contributes to improving fine art teaching methods.

This study has contributed to showing the variables in teaching fine arts in Jordanian universities by shedding light on showing standards for teaching fine arts that are essential and essential components of fine arts. And other creative areas, as it helps weak programs to develop and improve according to what was mentioned in those standards. They are indicators of how good and what art teaching methods should be. By analyzing the methods of teaching fine arts, the following recommendations and suggestions can be used:

- $\quad$ Looking at modern international trends to update art education curricula and methods that are numerous and varied, and are a rich source for taking in the development of arts programs of all kinds, and this is what educational institutions should strive for and emphasize at all levels.

- $\quad$ Seeking to teach and train fine arts students to use modern technology in their various studies and using them extensively helps to face new concepts in light of contemporary arts.

Focus on activating the approaches to modernizing fine arts curricula and teaching methods according to the studied scientific curriculum in cooperation with higher education institutions.

- Training students of fine arts to use multicultural resources while preserving the identity and characteristics of culture significantly impacts developing their critical thinking patterns.

By adopting the culture of teaching new arts and not contenting with traditional teaching methods in teaching fine arts of all kinds and levels; through the departments of art colleges in universities, and the need to adopt a draft of national standards to ensure the quality of preparing artists of different specializations and trends to contribute to controlling the quality of graduates in the arts.

Quality fine art teaching methods should include numerous original art projects using different materials, and diverse teaching approaches also take into account individual differences, preparations and differences at the student level, Professors of art, and the nature of the various disciplines; to provide art students with high and varied artistic skills, With theoretical knowledge of arts, its history, how to taste, criticize and evaluate it. The most important approaches to modernizing art education methods were reviewed through this study, and the researcher attempted to answer the research questions implicitly by reviewing studies, research, and literature related to the research topic. And these entries have been classified according to contemporary global trends and contributions, with analysis and criticism of them so that they are visible from a scientific perspective that can be adopted in the future.

\section{References}

Eckert, G. (2006). Art and How it Benefits the Brain. Self-help-Healing-Arts-Journa.1 Retrieved from: www.selfhelp-healing-artsjournal.com/artbenefits-brain.html. https://www.google.jo

Abdel Hay, S. (2006). The effect of using the computer strategy in teaching the Arabic calligraphy formation course on developing the innovative ability and academic achievement of the students of the Art Education Department at Umm Al-Qura University in Makkah. Master Thesis, College of Education: Umm Al-Qura University.

Abdel-Razek, I. (2002). Education in the Age of Globalization: Educational starting points for interacting with the movement of life. Education Magazine, Issue 104, Qatar. https://www.google.jo

Al-Hamid, A. (2003). Globalization, curriculum development mechanisms, its implications for teaching methods, and new teaching and curriculum building trends. Published research. Saudi. 
Zaitoun, A. (2008). University teaching methods. Sunrise House for Publishing and Distribution, Amman, Jordan. Habash, Z. (2002) Educational perspectives in teaching and creative learning. Phoenix Foundation for Renewal and Creativity, Ramallah, Palestine.

Khaza'leh, H. (2011), Muhammad and Al-Zaboon, Mansour and Al-Khaz'leh, Khaled and Al-Shobaki, Assaf and Al-Sukhni, Effective Teaching Methods. Dar Al-Safa for Printing and Publishing, Amman, Jordan. 